\title{
Anti-TTG among children with chronic functional constipation unresponsive to 6 weeks of treatment of constipation
}

\author{
Nooshin SADJADEI ${ }^{1}$, Samaneh HOSSEINMARDY ${ }^{2}$, Mehran HAKIMZADEH ${ }^{1}$, \\ Tahereh ZIAEI KAJBAF ${ }^{2}$ and Hazhir JAVAHERIZADEH ${ }^{1,3}$
}

Received 23/12/2016

Accepted 6/2/2017

ABSTRACT - Background - Celiac disease is a glutten induced enteropathy. Some authors recommended screening celiac in children with constipation. There are studies to evaluate celiac disease in children with constipation. But most of them included children regardless to treatment failure. Objective-The aim of this study was to evaluate frequency of elevated anti TTG in children with constipation after failure to improve during 6 week of appropriate treatment of constipation. Methods - In this cross sectional study, 550 children with prolonged constipation were included. Place of study was Pediatric Gastroenterology clinic of Abuzar children's hospital. Prolonged constipation was defined as a constipation which failed to resolved after 6 weeks of appropriate treatment. Constipation was defined according to ROME III criteria. After parental agreement, $5 \mathrm{~mL}$ of blood was obtained. Serum anti TTG level was measure using ELISA method by Orientec kit. Anti TTG>10 was considered positive if IgA was normal. SPSS version 16.0 (Chicago, IL, USA) was used for data analysis. Chi square, $t$-test, and Mann Whitney test used for data analysis. Results - In this study 550 children (m=277, $\mathrm{f}=273)$ were included. Mean age of the cases was $6.8 \pm 2.9$ year. Anti TTG antibody level was $5.8 \pm 2.8 \mathrm{unit} / \mathrm{mL}$. Of these case, $42(7.6 \%)$ had positive anti-TTG antibody. Celiac disease was confirmed in 40 cases after histopathology examination. Conclusion - Anti-TTG was positive in $7.6 \%$ children with chronic constipation who failed to respond after 6 week of treatment. Another multicenter study with longer follow up period is recommended.

HEADINGS - Celiac disease. Constipation. Transglutaminases.

\section{INTRODUCTION}

Celiac disease is a gluten induced enteropathy with estimated prevalence about $2 \%$ in some studies from $\operatorname{Iran}^{(4)}$. Constipation was reported in about $35 \%$ of cases with Celiac disease ${ }^{(7)}$. In previous studies, all children with constipation were evaluated for seropositivity of anti-TTG (anti Tissue Trasnglutaminse) and histopathology examination regardless to duration of constipation $^{(3)}$. According to recent guideline by ESPGHAN and NASPGHAN, it is not recommended to perform routine screening test for organic causes such a celiac disease, hypercalcemia, and hypothyrodisim ${ }^{(10)}$ but some physicians recommend such testing at initial visit.

In the current study, we investigated children with treatment failure for constipation after 6 weeks of appropriate treatment of constipation.

\section{METHODS}

Inclusion criteria were prolonged constipation. Organic disease, history of previous abdominal surgery, hypotonia, neurologic problem were exclusion criteria. This study was approved by Ethical
Committee of the University. In this study children aged 2-14 years old were included. Constipation were defined according to ROME III criteria. ROME III criteria were used for definition of constipation.

\section{Neonates and Toddlers}

"At least two of the following symptoms must occur for at least 1 month:

- $=<2$ defecations per week

- $>=1$ episode per week of incontinence after the acquisition of toileting skills

- History of excessive stool retention

- History of painful or hard bowel movements

- Presence of a large fecal mass in the rectum, and

- History of large- diameter stools that may obstruct the toilet"(5).

\section{Child and Adolescent}

"Symptoms must occur at least once per week for at least 2 months and include two or more of the following in a child with a development age of $>4$ years with insufficient criteria of irritable bowel syndrome: 
- Two or fewer defecations in the toilet per week

- At least one episode of fecal incontinence per week

- History of retentive posturing or excessive volitional stool retention

- History of painful or hard bowel movements

- Presence of a large fecal mass in the rectum

- History of a large diameter stools that may obstruct the toilet"(9).

Children who failed to respond after 6 weeks of treatment with laxative were included. Treatment was prescribed by a pediatric gastroenterologist. After parental agreement, $5 \mathrm{~mL}$ of blood were obtained. Orientec kit was used for anti-TTG measurement. Anti-TTG $>10$ unit $/ \mathrm{mL}$ was considered positive. $P$ value $<0.05$ was considered positive. Histologic examination was done by an experienced pathologist. Marsh-Oberhuber classification was used for evaluation of histologic specimen if needed. This study was approved by Ethical Committee of the University number IR.AJUMS.REC.1394.26.

\section{Data analysis}

Statistical Package for Social Sciences (SPSS) (Chicago, IL, USA) version 16.0 was used for data analysis. Chi square, $t$-test, and Mann Whitney test used for data analysis.

\section{RESULTS}

In this study 277 boys and 273 girls were included. Mean age of the cases was $6.8 \pm 2.9$ year. Relative frequency of children according to age group is seen in Table 1 .

In this study, Anti-TTG antibody level was $5.8 \pm 2.8$ unit $/ \mathrm{mL}$. From all subjects, Anti-TTG was considered positive in $42(7.6 \%)$ of cases. Anti TTG antibody was negative in $508(92.4 \%)$ of cases. Duration of constipation was $4.1 \pm 2.5$ years. Frequency of duration of constipation is seen in Table 2 .

TABLE 1 . Frequency of children with constipation

\begin{tabular}{cc}
\hline Age & $\mathbf{N}(\%)$ \\
\hline$<2$ & 1.10 \\
$2-5$ & 37.6 \\
$5-10$ & 46.20 \\
$>10$ & 14.90 \\
\hline
\end{tabular}

TABLE 2. Frequency of constipation according to duration of constipation

\begin{tabular}{cc}
\hline Duration of constipation & $\mathbf{N}(\%)$ \\
\hline$<1$ year & $8.10 \%$ \\
$1-2$ year & $17.30 \%$ \\
$2-5$ & $45.10 \%$ \\
$5-10$ & $28 \%$ \\
$>10$ & $1.50 \%$ \\
\hline
\end{tabular}

There was no correlation between age of the children with constipation and anti-TTG level (Figure 1).

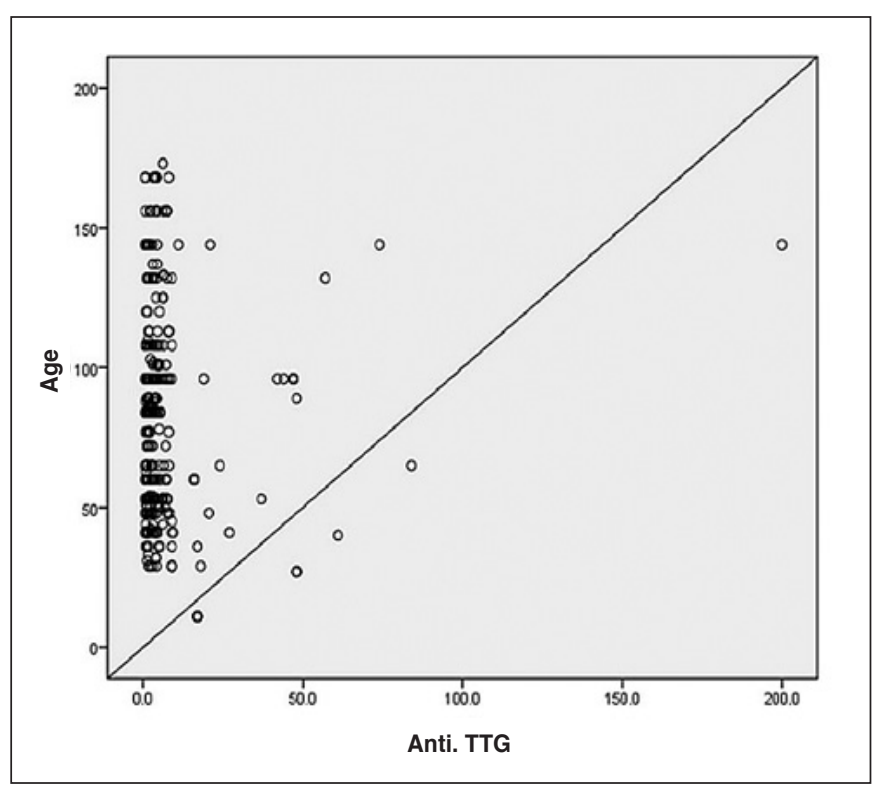

FIGURE 1. Correlation between age of children and anti-TTG level

As seen in Table 3, there was no significant difference between male and female in terms of level of anti-TTG $(P=0.27)$.

TABLE 3. Level of Anti-TTG antibody between male and female

\begin{tabular}{ccc}
\hline $\begin{array}{c}\text { Anti-TTG } \\
(\text { mean } \pm \text { SD })\end{array}$ & Sex & $P$ value \\
\hline $5.2 \pm 0.5$ & Male & 0.27 \\
$6.4 \pm 0.9$ & Female & \\
\hline
\end{tabular}

There was no correlation between anti-TTG level and age of cases $(P=0.649, \mathrm{r}=0.019)$ (Figure 1, Table 4). There was no correlation between anti-TTG level and sex of the children $(P=0.120$, $\mathrm{r}=0.066$ ) (Figure 2).

TABLE 4. Anti-TTG antibody level among different age group

\begin{tabular}{ccc}
\hline $\begin{array}{c}\text { Anti-TTG } \\
(\text { mean } \pm \text { SD })\end{array}$ & Age range & $P$ value \\
$5.3 \pm 0.0$ & $<2$ year & \\
$6.1 \pm 0.6$ & $2-5$ years & \\
$4.6 \pm 0.6$ & $5-10$ years & \\
$7.7 \pm 2.6$ & $>10$ years \\
\hline
\end{tabular}




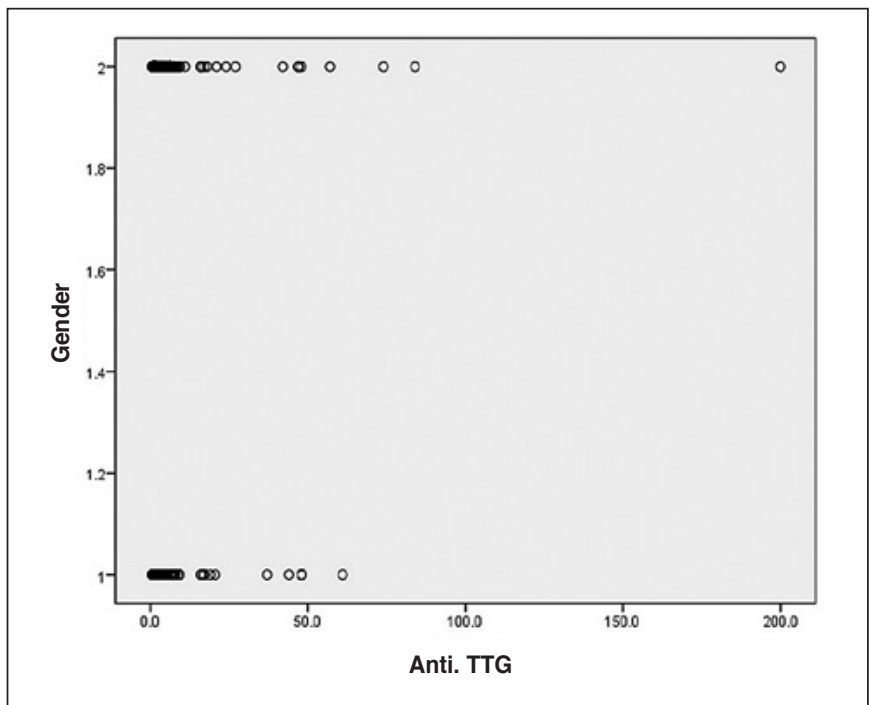

FIGURE 2. Gender and Anti-TTG level in children with chronic constipation

\section{DISCUSSION}

In our study, mean of age was 6.8 \pm 2.9 . In Dehghani et al. study, mean age of the cases was $4.8 \pm 2.5$ years $^{(3)}$.

In our study, anti-TTG was positive in $42(7.6 \%)$ of cases. In another study from Turkey, Anti TTG was positive in $2.5 \%$ of children with chronic constipation $^{(1)}$. In the study from Netherland, of 370 cases with constipation, anti-TTG was positive in seven subjects ${ }^{(8)}$. Of 101 children in Dehghani et al. study, 4 (3.96\%) had positive anti-TTG level. In another study from India, of 137 children with constipation, $2(1.5 \%)$ had celiac disease ${ }^{(6)}$.

Of three cases with positive anti-TTG level who underwent endoscopy in Dehghani et al. study, only one case had biopsy proven celiac disease $^{(3)}$. In our study, of 42 cases with positive anti-TTG level, 40 cases had evidence of celiac disease in biopsy samples. Higher rate of diagnosis of celiac disease in our study compared to Dehghani et al. study may be due to difference in experience of pathologists in two studies. Also, in the current study, cases who did not respond to medical treatment after 6 weeks were included. But in Dehghani et al. study, children were included regardless treatment response ${ }^{(3)}$.

In Dehghani et al. study, $53.5 \%$ of cases were boys and $46.5 \%$ were girls and was similar to our study(3).

In our study, there was no significant difference between boy and girls in terms of anti-TTG antibody titer. In Dehghani et al. study, there was no significant difference between girls and boys for anti-TTG antibody ${ }^{(3)}$.

In the study by Chogle et al., constipation alone did not increase the likelihood of celiac disease ${ }^{(2)}$. In the study by Dehghani et al., they did not recommend routine check of anti-TTG antibody for patients with constipation ${ }^{(3)}$.

\section{CONCLUSION}

In conclusion, according to these study, constipation alone did not increase possibility of celiac disease significantly. Testing for celiac disease may be appropriate for children who failed to show response after 6 weeks of treatment. Further studies are recommended to optimal duration of treatment of constipation before celiac testing.

\section{ACKNOWLEDGEMENT}

Data was used in this paper was issued from residency thesis of Samaneh Hosseinmardy (No. U94010). This study was supported by research affair of Ahvaz Jundishapur University of Medical Sciences. We acknowledged Dr. Amal Saki for data analysis.

\section{Authors' contributions}

Sadjadei N: supervision of thesis, main idea, and data collection. Hosseinmardy $\mathrm{S}$ : writing draft of proposal and data collection. Hakimzadeh M: data collection and revision of proposal. ZiaeiKajbaf T: literature search and supervision of thesis. Javaherizadeh $\mathrm{H}$ : writing manuscript, revision of manuscript and final approval.

Sadjadei N, Hosseinmardy S, Hakimzadeh M, Ziaei-Kajbaf T, Javaherizadeh H. Anti-TTG entre crianças com constipação funcional crônica não responsivas após 6 semanas de tratamento da constipação. Arq Gastroenterol. 2017;54(3):197-200.

RESUMO - Contexto - A doença celíaca é uma enteropatia glúten-induzida. Alguns autores recomendam a triagem de doença celíaca em crianças com constipação. Há estudos para avaliar a doença celíaca em crianças com constipação, mas a maioria inclue crianças independentemente do insucesso do tratamento. Objetivo - O objetivo deste estudo foi avaliar a frequência de anti-TTG elevado em crianças com constipação após 6 semanas de tratamento adequado e sem sucesso. Métodos - Através de cruzamento seccional, 550 crianças com constipação prolongada foram incluídas. O local de estudo foi o ambulatório de Gastroenterologia Pediátrica do Hospital Infantil de Abuzar. Constipação prolongada foi definida como uma constipação, cuja resolução falhou após 6 semanas de tratamento adequado. Constipação foi definida de acordo com critérios de Roma III. Após o consentimento informado dos pais, obteve-se $5 \mathrm{~mL}$ de sangue. O nível de anti TTG no soro foi medido usando-se o método ELISA pelo Orientec kit. O anti-TTG $>10$ foi considerado positivo se IgA estivesse normal. Os dados foram analisados através de testes do Chi-quadrado, $t$-teste e teste de Mann Whitney utilizando-se o SPSS versão 16.0 (Chicago, IL, EUA). Resultados - Um total de 550 crianças $(\mathrm{m}=277$, f=273) foi incluído neste estudo. A média de idade dos pacientes foi 6,8 $\pm 2,9$ anos. O nível de anticorpo anti-TTG foi de 5,8 $\pm 2,8$ unidades $/ \mathrm{mL}$. Do total, 42 (7,6\%) indivíduos tinham anticorpos anti-TTG positivo. A doença celíaca foi confirmada em 40 casos após exame de histopatologia. Conclusão-O Anti-TTG foi positivo em 7,6\% crianças com constipação crônica que não conseguiram responder após 6 semanas de tratamento. Outro estudo multicêntrico, com acompanhamento mais longo período é recomendado.

DESCRITORES - Doença celíaca. Constipação intestinal. Transglutaminases. 


\section{REFERENCES}

1. Cakir M, Cezaroglu S, Cobanoglu U. Celiac disease in children with chronic constipation. Turk J Med Sci. 2016;46:651-6.

2. Chogle A, Saps M. Yield and cost of performing screening tests for constipation in children. Can J Gastroenterol. 2013;27:e35-8.

3. Dehghani SM, Ehsaei Z, Honar N, Javaherizadeh H. Frequency of Celiac Disease In Children With Chronic Functional Constipation in Shiraz-Iran. Middle Eas J Dig Dis. 2015;7:166-9.

4. Dehghani SM, Haghighat M, Mobayen A, Rezaianzadeh A, Geramizadeh B. Prevalence of celiac disease in healthy Iranian school children. Ann Saudi Med. 2013,33:159-61

5. Hyman PE, Milla PJ, Benninga MA, Davidson GP, Fleisher DF, Taminiau J. Childhood functional gastrointestinal disorders: neonate/toddler. Gastroenterology. 2006;130:1519-26.
6. Khanna V, Poddar U, Yachha SK: Etiology and clinical spectrum of constipation in Indian children. Indian Pediatr. 2010,47:1025-30.

7. Khatib M, Baker RD, Ly EK, Kozielski R, Baker SS. Presenting Pattern of Pediatric Celiac Disease. J Pediatr Gastroenterol Nutr. 2016,62:60-3.

8. Pelleboer RA, Janssen RL, Deckers-Kocken JM, Wouters E, Nissen AC, Bolz WE, Ten WE, van der Feen C, Oosterhuis KJ, Rovekamp MH, et al. Celiac disease is overrepresented in patients with constipation. J Pediatr (Rio J). 2012;88:173-6.

9. Rasquin A, Di Lorenzo C, Forbes D, Guiraldes E, Hyams JS, Staiano A, Walker LS. Childhood functional gastrointestinal disorders: child/adolescent. Gastroenterology. 2006;130:1527-37.

10. Tabbers MM, DiLorenzo C, Berger MY, Faure C, Langendam MW, Nurko S Staiano A, Vandenplas Y, Benninga MA. Evaluation and treatment of functiona constipation in infants and children: evidence-based recommendations from ESPGHAN and NASPGHAN. J Pediatr Gastroenterol Nutr. 2014;58:258-74. 